\title{
Variation and genetic structure of the endangered Lepus flavigularis (Lagomorpha: Leporidae)
}

\author{
Bárbara Cruz-Salazar1*, Consuelo Lorenzo ${ }^{1}$, Eduardo E. Espinoza-Medinilla ${ }^{2}$ \& Sergio López ${ }^{2}$ \\ 1. El Colegio de la Frontera Sur, Unidad San Cristóbal de Las Casas, Chiapas, Carretera Panamericana s/n Barrio María \\ Auxiliadora, CP 29200, San Cristóbal de las Casas, Chiapas, México; bcruz@ecosur.edu.mx, clorenzo@ecosur.mx \\ 2. Universidad de Ciencias y Artes de Chiapas, $1^{\text {a }}$. Sur Poniente 1460, CP 29290, Tuxtla Gutiérrez, Chiapas, México; \\ eduardo.espinoza@unicach.mx, sergio.lopez@unicach.mx \\ * Correspondencia
}

Received 03-II-2017. Corrected 10-VII-2017. Accepted 09-VIII-2017.

\begin{abstract}
Lepus flavigularis, is an endemic and endangered species, with only four populations inhabiting Oaxaca, México: Montecillo Santa Cruz, Aguachil, San Francisco del Mar Viejo and Santa María del Mar. Nevertheless, human activities like poaching and land use changes, and the low genetic diversity detected with mitochondrial DNA and allozymes in previous studies, have supported the urgent need of management strategies for this species, and suggest the definition of management units. For this, it is necessary to study the genetic structure with nuclear genes, due to their inheritance and high polymorphism, therefore, the objective of this study was to examine the variation and genetic structure of L. flavigularis using nuclear microsatellites. We sampled four populations of $L$. flavigularis and a total of 67 jackrabbits were captured by night sampling during the period of 2001 to 2006. We obtained the genomic DNA by the phenol-chloroform-isoamyl alcohol method. To obtain the diversity and genetic structure, seven microsatellites were amplified using the Polymerase Chain Reaction (PCR); the amplifications were visualized through electrophoresis with $10 \%$ polyacrylamide gels, dyed with ethidium bromide. Genetic diversity was determined using the software GenAlEx v. 6.4, and genetic structure was obtained with ARLEQUIN v. 3.1; null alleles were evaluated using the program Micro-Checker v.2.2.2. Additionally, a Bayesian analysis was performed with software STRUCTURE v. 2.2.3., and the isolation by distance (IBD) was studied using the program PASSAGE v.2.0.11.6. Our results showed that the genetic variation found was low $\left(H_{O}=0.30, H_{E}=0.24\right)$ when compared to other jackrabbit species. Fixed alleles and moderate levels of genetic differentiation $\left(F_{\mathrm{ST}}=0.18, \mathrm{P}=0.001\right)$ were detected among populations, indicating the effect of the genetic drift and limited gene flow. Bayesian clustering analysis revealed two groups: (1) jackrabbits from Montecillo Santa Cruz, and (2) individuals living in Aguachil, San Francisco del Mar Viejo and Santa María del Mar. No evidence was found of isolation by distance. It is possible that the geographic barriers present between populations (e.g. lagoons, human settlements), rather than the geographical distance between them, may explain the observed genetic structure. The inbreeding coefficient was negative $\left(F_{I S}=-0.27, \mathrm{P}=\right.$ 0.03 ), indicating genetic sub-structure in populations. We suggest two management units based on the genetically closer populations, which will help define precise conservation actions in L. flavigularis. This research is the basis for defining translocation of individuals between populations, nevertheless, a more extensive future study, with specific molecular markers for L. flavigularis, is required. In addition, it is necessary to analyze the barriers that limit the gene flow, since it is urgent to reduce the genetic differentiation between populations and increase the genetic diversity of this species. Rev. Biol. Trop. 65 (4): 1322-1336. Epub 2017 December 01.
\end{abstract}

Key words: conservation genetics, endemic species, Lepus flavigularis, management units, microsatellites, tropical jackrabbit.

In general, endemic species live in small populations with a restricted geographic distribution, usually being specialists and more vulnerable to extinction than species with a broad distribution, because their survival is directly related to specific environmental conditions, that can be altered by human activities, and affect their reproduction, feeding, dispersal 
and genetic diversity (Keyghobadi, 2007; Schooley \& Branch, 2011; Ripperger, Tschapka, Kalko, Rodríguez-Herrera, \& Mayer, 2014). Genetic variation can be measured through heterozygosity and polymorphism (genotypes and alleles, respectively) within and between populations, and is affected by population size, natural selection, mutation, gene flow, inbreeding and genetic drift (Mace, Smith, Bruford, \& Wayne, 1996; Frankham, Ballou, \& Briscoe, 2002; Wilson et al., 2005). The interruption of gene flow contributes to fixation of alleles by genetic drift or natural selection, which modify the levels of genetic variation and differentiation between populations, thereby influencing the genetic structure (Templeton, 1986; Templeton, Shaw, Routman, \& Scott, 1990; Mech $\&$ Hallet, 2001). Decrease of genetic variation reduces population viability and the ability of species to adapt to environmental changes (Wilson et al., 2005).

The Tehuantepec jackrabbit, Lepus flavigularis (Wagner, 1844), is a endemic species to Oaxaca, México, whose distribution has been reduced to only four isolated populations with less than 1000 individuals; so that has been listed as an endangered species (Lorenzo, Cervantes, Barragán, \& Vargas, 2006; Smith, 2008; IUCN 2015; Lorenzo, Rioja-Paradela, \& Carrillo-Reyes, 2015). Previous studies have reported low population density, polygamous and non-territorial habits, as well as a large home range that depends on the availability of resources and varies significantly between sexes: from 1.13 ha to 152.61 ha in females and from 0.20 ha to 71.87 ha in males (Farías et al., 2006; Lorenzo, Rioja, Carrillo, \& Cervantes, 2008; Carrillo-Reyes, Lorenzo, Naranjo, Pando, \& Rioja, 2010). It is known that its populations are threatened by poaching, predation by dogs and habitat loss (Lorenzo, Cervantes, \& Vargas, 2005; CarrilloReyes, Lorenzo, Rioja-Paradela, Naranjo, \& Pando, 2012; Rioja-Paradela, Carrillo-Reyes, \& Lorenzo, 2012; Sántiz, Lorenzo, CarrilloReyes, Navarrete, \& Islebe, 2016). In addition, a low genetic diversity and moderate genetic structure among populations, was detected with mitochondrial DNA (mDNA) and allozymes (Cervantes, Lorenzo, \& Yates, 2002; Rico, Lorenzo, González-Cózatl, \& Espinoza, 2008). This information suggests the development of management strategies to enhance the gene flow and to increase the levels of genetic diversity, in order to improve the evolutionary ability to respond to environmental changes, as part of a conservation program for L. flavigularis.

Management units (MU) help conservation because they are useful for genetic and demographic monitoring, they group populations that share allelic frequencies, and separate populations with significant genetic divergence (Moritz, 1994). To define management units in L. flavigularis it is necessary to study the genetic structure with nuclear genes, particularly microsatellites, which are widely used in conservation genetics, because they display high polymorphism rates, are codominant, neutral and distributed abundantly throughout the genome, all of which help to detect bottlenecks and gain a better understanding of genetic variation and population structure (Maudet et al., 2002; Freeland, 2005; Encinas, da Silva, da Silva, da Silva, \& Sebbenn, 2016). Accordingly, the aim of this research was to determine the variation levels and genetic structure of the four existing populations of L. flavigularis using nuclear microsatellites, in order to compare our results with the data available (Cervantes et al., 2002; Rico et al., 2008), and thereby determine the proper genetic management required for future conservation strategies. Based on previous studies and the knowledge of the current pressures that threaten L. flavigularis, our expectation was to find a low genetic variation and a genetic structure based on the geographic distance between populations.

\section{MATERIAL AND METHODS}

Study site: The study area is located in the Isthmus of Tehuantepec, state of Oaxaca, Mexico, in coordinates $16^{\circ} 28^{\prime} 30^{\prime \prime}-16^{\circ} 28^{\prime} 44^{\prime \prime}$ N \& 94 $28^{\circ} 06^{\prime \prime}$ - 94 $54^{\circ}$ '53" W (Ortiz, Hernández, \& Figueroa, 2004) (Fig. 1). The climate in the area is hot, sub-humid, with rainfall from 


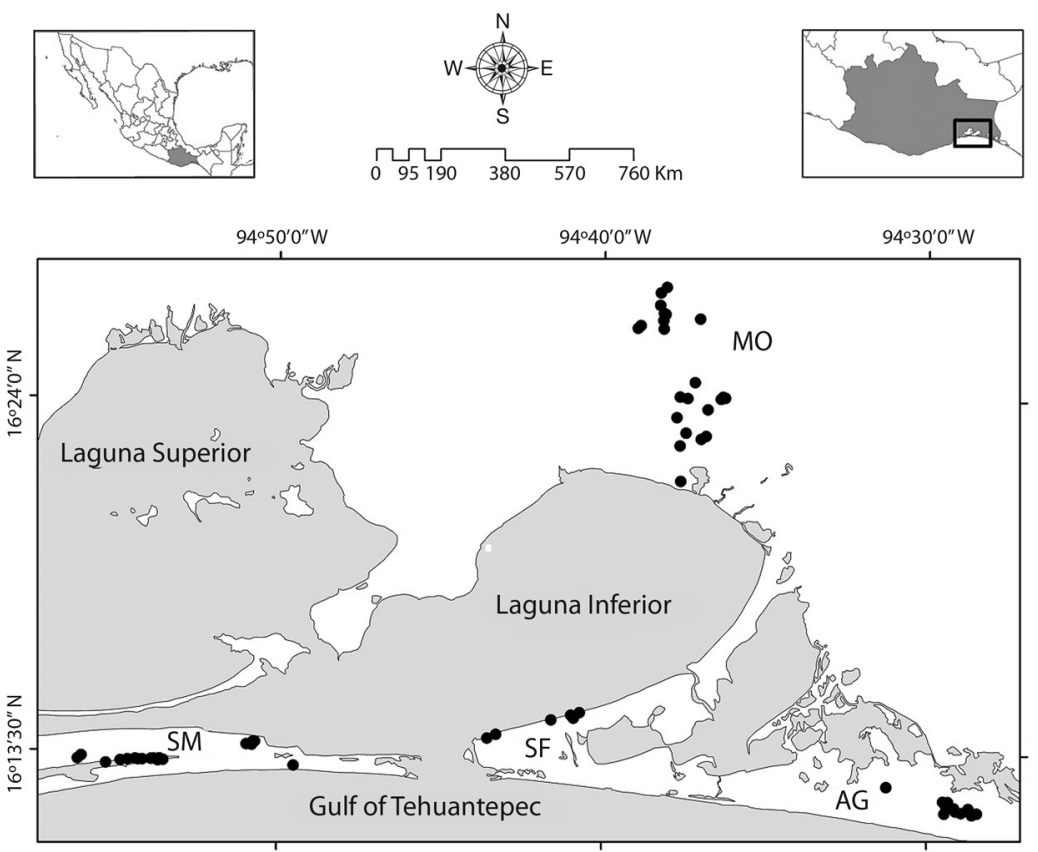

Fig. 1. Sampling locations of the L. flavigularis in Oaxaca, México. AG = Aguachil, SF = San Francisco del Mar Viejo, $\mathrm{MO}=$ Montecillo Santa Cruz, SM = Santa María del Mar. Dots mark the locations where the jackrabbits were captured.

May to October and dry from November to April (Zizumbo \& Colunga, 1982). The mean annual temperature is $27.6^{\circ} \mathrm{C}$ and the total annual precipitation is $932.2 \mathrm{~mm}$ (García, 1988). The vegetation is composed of bush, mangrove and some extensive areas of savanna with dispersed trees (Crescentia alata) and shrubs (Byrsonima crassifolia). In the driest parts, there are tropical low deciduous and low spiny deciduous forest. Aristida, Bouteloua, Cathestecum, Cenchrus, Digitaria, Eragrostis, Panicum, Paspalum and Schizachyrium are Gramineae that dominates the savannas and introduced grasslands (Sántiz et al., 2012; Sántiz, González-Romero, Lorenzo, GallinaTessaro, \& Cervantes, 2016).

Four existing populations of L. flavigularis were studied, all located in the Southern Isthmus of Tehuantepec. The locations of these populations are: (1) Montecillo Santa Cruz (MO), North of Laguna Inferior; (2) San Francisco del Mar Viejo (SF) to the South of Laguna Inferior; (3) Aguachil (AG), Southeast of Laguna Inferior; and (4) Santa María del Mar
(SM), South of Laguna Superior (Cervantes, Lorenzo, Farías, \& Vargas, 2008; Lorenzo et al., 2014; IUCN, 2015) (Fig. 1). The average geographical distances between the populations were: $20.5 \mathrm{~km}$ between Aguachil and San Francisco del Mar Viejo, $25.0 \mathrm{~km}$ between Aguachil and Montecillo Santa Cruz, $45.2 \mathrm{~km}$ between Aguachil and Santa María del Mar, $18.0 \mathrm{~km}$ between San Francisco del Mar Viejo and Montecillo Santa Cruz, $25.3 \mathrm{~km}$ between San Francisco del Mar Viejo y Santa María del Mar, and $37.50 \mathrm{~km}$ between Montecillo Santa Cruz and Santa María del Mar.

The four populations of L. flavigularis are strongly threatened by poaching and habitat destruction for livestock use. In addition, the predation by domestic animals (e.g. dogs) that occurs in Santa María del Mar, as well as the burnings for agricultural maintenance, reduce native pastures and increase the vulnerability of populations of Montecillo Santa Cruz and San Francisco del Mar Viejo (Carrillo et al., 2010; 2012). 
Sampling work: Jackrabbits were sampled by nocturnal field trips of 15 days each time during 2001 to 2006, during the rainy and dry seasons. Specifically, from February to April 2001, November 2003, March 2004, December 2004, January and April 2005, and March, June and July 2006. Specimens were captured with trawler-like nets. The detailed geographic position of each individual captured was determined by a Global Positioning System (GPS). Discs of tissue with a circumference of approximately $5 \mathrm{~mm}$ were removed from the ear of a total of 67 jackrabbits (from the four populations) by puncturing; tissue samples were preserved in Eppendorf tubes filled with $95 \%$ ethanol for genetic analysis. Immediately afterwards, individuals were released. The capture and collection of jackrabbits tissue were carried out with collection permits of the General Direction of Wildlife of México (SEMARNAT; number SGPA/DGVS/02094/07), and according to the guidelines of the American Society of Mammalogists for use of wild mammals in research (Gannon, sinkers, \& The animal care and use committee of the American Society of Mammalogists, 2007).

DNA extraction and microsatellite analysis: In the laboratory, the genomic DNA of each tissue sample was extracted according to the standard protocol involving proteinase $\mathrm{K}$ digestion, followed by phenol/chloroform separation and a final precipitation with ethanol as described by Hamilton, Pincus, Di Fiore \& Fleischer (1999). The molecular markers used were seven different microsatellite loci (Sat 2, Sat 3, Sat 5, Sat 12, Sat 13, Sol 33 and Sol $44)$, originally isolated in the European rabbit (Oryctolagus cuniculus) (Mougel, Mounolou, \& Monnerot, 1997; Surridge, Bell, Rico, \& Hewitt, 1997) (Appendix). Double-chain products were amplified through Polymerase Chain Reaction (PCR) with the master mix (Mastermix; PROMEGA ${ }^{\circledR)}$ in a PTC-100 Thermal cycler (Thermal Peltier Cycler ${ }^{\circledR}$ ). Standard amplification conditions consisted of a denaturation initial at $94{ }^{\circ} \mathrm{C}$ for $5 \mathrm{~min}, 30$ cycles with a denaturation step at $94{ }^{\circ} \mathrm{C}$ for $30 \mathrm{~s}$, an alignment step at $55-69{ }^{\circ} \mathrm{C}$ for $30 \mathrm{~s}$, an extension step at $72{ }^{\circ} \mathrm{C}$ for $30 \mathrm{~s}$ each, and a final extension at $72{ }^{\circ} \mathrm{C}$ for $10 \mathrm{~min}$ (Mougel et al., 1997; Surridge et al., 1997). The amplifications were visualized using electrophoresis with $10 \%$ polyacrylamide gels, dyed with ethidium bromide and observed under UV light with the 1D Image Analysis Software v. 3.6 to record the genotype by locus and individual (Valadez $\&$ Kahl, 2000). The location of alleles in each microsatellite locus was determined according to the base-pair (bp) interval reported in the literature (Mougel et al., 1997; Surridge et al., 1997) and with a 100 bp ladder as a control (PROMEGA).

Genetic variation was measured in terms of the number of alleles $\left(N_{A}\right)$, percent polymorphic loci (polymorphism), observed heterozygosity $\left(H_{O}\right)$, expected heterozygosity $\left(H_{E}\right)$, and inbreeding coefficient $\left(F_{I S}\right)$ using the software GenAlEx v.6.4 (Peakall \& Smouse, 2006). The Hardy-Weinberg equilibrium (HWE) was evaluated by locus with the same software, and HWE by population was obtained with a combination of independent probabilities tests (Sokal \& Rohlf, 2003). The significance of $F_{\text {IS }}$ was calculated through a Chi-square test $\left(\chi^{2}\right)$ using the following expression: $\chi^{2}=N F_{I S}^{2}$, where $N$ is sample size with one degree of freedom (Hedrick, 2005).

To assess whether populations were genetically different and estimate their degree of genetic structure, the $F_{S T}$ index was calculated based on Weir and Cockerham (1984) using ARLEQUIN v. 3.1. (Excoffier, Smouse, \& Quattro, 1992; Excoffier \& Lischer, 2010). The distribution of the genetic variation was evaluated between and within populations through an AMOVA (Excoffier \& Lischer, 2010). The $F_{S T}$ significance was calculated with a Chisquare test $\left(\chi^{2}\right)$ using the expression: $\chi^{2}=$ $2 N F_{S T}$, where $N$ is sample size with one degree of freedom (Hedrick, 2005).

Null alleles were determined using the program Micro-Checker v. 2.2.2. (Van Oosterhout, Hutchinson, Willis, \& Shipley, 2004). Using the Free-NA program (Chapuis \& Estoup, 2007), $F_{S T}$ corrected for null alleles 
was estimated by means of the ENA (Excluding Null Alleles) method $\left(F_{S T-E N A}\right)$, and the $F_{S T}$ corrected for null alleles was computed using the INA (Including Null Alleles) method $\left(F_{\text {ST-INA }}\right)$. We also estimated the Cavalli-Sforza and Edwards genetic distance for each pair of populations (Cavalli-Sforza \& Edwards, 1967), with the ENA method $\left(D_{C-E N A}\right)$ and the INA method $\left(D_{C-I N A}\right)$. The dendrograms were based on the Cavalli-Sforza and Edwards (1967) genetic distance obtained using the software PHYLIP v. 3.69. In addition, we used the Bayesian clustering method implemented in the software STRUCTURE v. 2.2.3. (Pritchard, Stephens, \& Donnelly, 2000; Falush, Stephens, \& Pritchard, 2003) to infer the most likely number of genetic clusters $(K)$ in L. flavigularis. The analysis was performed without prior information, $K$ values from one to ten, a burn-in of 50000 and 100000 iterations of the Markov Chains Monte Carlo model (MCMC), assuming correlated allele frequencies among populations and an admixture model (i.e. gene flow). The most probable number of clusters was chosen by using the statistics $\Delta K$, which is based on the rate of change in the probability of data between successive $K$ values (Evanno, Regnaut, \& Goudet, 2005). Individuals were assigned to a cluster according to the $Q$-value $(\geq 0.7)$; if an individual showed a $Q$-value $\leq$ 0.7 , it was classified as unknown (Hennessy et al., 2015; Cruz-Salazar et al., 2016).
Finally, to assess whether genetic differentiation follows a pattern of isolation by geographical distance (IBD), the Euclidean geographical distances between populations were obtained through the program ArcGis v. 10.2 (ESRI, 2011); and then a simple Mantel test was performed between the Nei genetic distance $(1972 ; 1978)$ and geographic distance, between the genetic differentiation $\left(F_{S T}\right)$ and geographic distance, and between the linearized genetic differentiation $\left(F_{S T} / 1-F_{S T}\right)$ and geographic distance (log), with 10000 permutations using the software PASSaGE 2 v.2.0.11.6. (Rosenberg \& Anderson, 2011).

\section{RESULTS}

Santa María del Mar showed the highest percentage of polymorphic loci (71.43), while San Francisco del Mar Viejo displayed the lowest (42.86). Likewise, San Francisco del Mar Viejo showed the lowest average of alleles (1.29) and observed heterozygosity (0.25) (Table 1). The average percentage of polymorphic loci was $57.14 \%$, the observed heterozygosity was $H_{O}=0.30$, and the expected heterozygosity was $H_{E}=0.24$.

The inbreeding coefficient $\left(F_{I S}\right)$ was negative in the four populations; however, statistical significance was detected only in jackrabbits from Montecillo Santa Cruz $\left(F_{I S}=\right.$ $-0.44, \mathrm{P}=0.03)$ (Table 1). Our results showed

TABLE 1

Genetic variation and Hardy-Weinberg Equilibrium (HWE) of L. flavigularis, obtained with seven microsatellite loci

\begin{tabular}{lcccccccccc}
\multicolumn{1}{c}{ Population } & $\mathrm{N}$ & $\mathrm{N}_{\mathrm{A}}$ & $\mathrm{N}_{\mathrm{E}}$ & $\mathrm{P}(\%)$ & $\mathrm{H}_{\mathrm{O}}$ & $\mathrm{H}_{\mathrm{E}}$ & $\mathrm{H}_{\mathrm{E}-\mathrm{INA}}$ & $\mathrm{F}_{\mathrm{IS}}$ & $\chi^{2}$ \\
$\mathrm{AG}$ & 15 & 1.57 & 1.32 & 57.14 & 0.30 & 0.25 & 0.38 & $-0.26^{\mathrm{NS}}$ & 7.24 \\
$\mathrm{SF}$ & 7 & 1.29 & 1.19 & 42.86 & 0.25 & 0.20 & 0.21 & $-0.37^{\mathrm{NS}}$ & $6.53^{*}$ \\
$\mathrm{MO}$ & 25 & 2.14 & 1.56 & 57.14 & 0.38 & 0.26 & 0.24 & $-0.44^{*}$ & $14.99^{* * *}$ \\
$\mathrm{SM}$ & 20 & 1.71 & 1.44 & 71.43 & 0.28 & 0.25 & 0.26 & $-0.20^{\mathrm{NS}}$ & $10.78^{* *}$ \\
Average & & 1.68 & 1.38 & 57.14 & 0.30 & 0.24 & 0.27 & $-0.32^{* *}$ & $50.32^{* * *}$ \\
\hline
\end{tabular}

$\mathrm{N}=$ sample size by population, $\mathrm{N}_{\mathrm{A}}=$ alleles number, $\mathrm{N}_{\mathrm{E}}=$ exclusive alleles, $\mathrm{P}=$ percentage of polymorphic loci, $\mathrm{H}_{\mathrm{O}}=$ observed heterozygosity, $\mathrm{H}_{\mathrm{E}}$ = expected heterozygosity, $\mathrm{H}_{\mathrm{E}-\mathrm{INA}}=$ expected heterozygosity including null alleles, $\mathrm{F}_{\mathrm{IS}}=$ inbreeding coefficient, $\chi^{2}=$ Chi-square for tests of Hardy-Weinberg Equilibrium.

$\mathrm{AG}=$ Aguachil, $\mathrm{SF}=$ San Francisco del Mar Viejo, $\mathrm{MO}=$ Montecillo Santa Cruz, SM = Santa María del Mar.

${ }^{*}=\mathrm{P}<0.05,{ }^{* *}=\mathrm{P}<0.01,{ }^{* * *}=\mathrm{P}<0.001,{ }^{\mathrm{NS}}=$ non-significant. 
that Montecillo Santa Cruz had the highest average number of alleles per population (2.14) and the higher values of observed heterozygosity (0.38) (Table 2).

Six out of the seven loci studied were polymorphic in the four populations of $L$. flavigularis. The Sol 33 locus had one fixed allele in the four populations (Table 2). The highest number of alleles per locus (four) was found on Sat 5 and Sol 44 (Table 2). The average number of alleles obtained in all populations was 1.68. Jackrabbits from Montecillo

TABLE 2

Allelic frequencies and Chi-square $\left(\chi^{2}\right)$ values for tests of Hardy-Weinberg Equilibrium (HWE) of seven microsatellites loci in L. flavigularis

\begin{tabular}{|c|c|c|c|c|c|}
\hline Locus & $f$ & $\mathrm{AG}$ & SF & MO & SM \\
\hline \multirow[t]{4}{*}{ Sat 2} & $\mathrm{a}$ & 0.79 & 0.58 & 1 & 1 \\
\hline & $\mathrm{b}$ & 0.21 & 0.42 & 0.00 & 0.00 \\
\hline & $\mathrm{c}$ & 0.00 & 0.00 & 0.00 & 0.00 \\
\hline & $\mathrm{d}$ & 0.00 & 0.00 & 0.00 & 0.00 \\
\hline$\chi^{2}$ & & $1.04^{\mathrm{NS}}$ & $3.06^{\mathrm{NS}}$ & - & - \\
\hline \multirow[t]{4}{*}{ Sat 3} & $\mathrm{a}$ & 0.58 & 0.5 & 1 & 0.5 \\
\hline & $\mathrm{b}$ & 0.42 & 0.5 & 0.00 & 0.5 \\
\hline & $\mathrm{c}$ & 0.00 & 0.00 & 0.00 & 0.00 \\
\hline & d & 0.00 & 0.00 & 0.00 & 0.00 \\
\hline$\chi^{2}$ & & $0.14^{\mathrm{NS}}$ & $0.2^{\mathrm{NS}}$ & - & $20.00^{* * *}$ \\
\hline \multirow[t]{4}{*}{ Sat 5} & $\mathrm{a}$ & 1 & 1 & 0.5 & 0.6 \\
\hline & $\mathrm{b}$ & 0.00 & 0.00 & 0.44 & 0.4 \\
\hline & $\mathrm{c}$ & 0.00 & 0.00 & 0.03 & 0.00 \\
\hline & $\mathrm{d}$ & 0.00 & 0.00 & 0.03 & 0.00 \\
\hline$\chi^{2}$ & & - & - & $18.00^{*}$ & $6.81^{*}$ \\
\hline \multirow[t]{4}{*}{ Sat 12} & $\mathrm{a}$ & 0.88 & 1 & 0.82 & 0.65 \\
\hline & $\mathrm{b}$ & 0.12 & 0.00 & 0.18 & 0.35 \\
\hline & $\mathrm{c}$ & 0.00 & 0.00 & 0.00 & 0.00 \\
\hline & $\mathrm{d}$ & 0.00 & 0.00 & 0.00 & 0.00 \\
\hline$\chi^{2}$ & & $0.08^{\mathrm{NS}}$ & - & $1.21^{\mathrm{NS}}$ & $0.20^{\mathrm{NS}}$ \\
\hline \multirow[t]{4}{*}{ Sat 13} & $\mathrm{a}$ & 0.36 & 0.83 & 0.84 & 0.65 \\
\hline & $\mathrm{b}$ & 0.5 & 0.17 & 0.16 & 0.35 \\
\hline & $\mathrm{c}$ & 0.14 & 0.00 & 0.00 & 0.00 \\
\hline & d & 0.00 & 0.00 & 0.00 & 0.00 \\
\hline$\chi^{2}$ & & $5.2^{\mathrm{NS}}$ & $0.12^{\mathrm{NS}}$ & $0.91^{\mathrm{NS}}$ & $0.16^{\mathrm{NS}}$ \\
\hline \multirow[t]{4}{*}{ Sol 33} & $\mathrm{a}$ & 1 & 1 & 1 & 1 \\
\hline & $\mathrm{b}$ & 0.00 & 0.00 & 0.00 & 0.00 \\
\hline & $\mathrm{c}$ & 0.00 & 0.00 & 0.00 & 0.00 \\
\hline & d & 0.00 & 0.00 & 0.00 & 0.00 \\
\hline$\chi^{2}$ & & - & - & - & - \\
\hline \multirow[t]{4}{*}{ Sol 44} & $\mathrm{a}$ & & & 0.5 & 0.95 \\
\hline & $\mathrm{b}$ & & & 0.1 & 0.05 \\
\hline & $\mathrm{c}$ & & & 0.16 & 0.00 \\
\hline & d & & & 0.24 & 0.00 \\
\hline$\chi^{2}$ & & NA & NA & $25.00^{* * *}$ & $0.05^{\mathrm{NS}}$ \\
\hline
\end{tabular}

$f=$ allelic frequency, $-=$ no Chi-square test due to fixed alleles, $\mathrm{NA}=$ no amplification. $\mathrm{AG}=$ Aguachil, $\mathrm{SF}=\mathrm{San}$ Francisco del Mar Viejo, MO = Montecillo Santa Cruz, SM = Santa María del Mar.

${ }^{*}=\mathrm{P}<0.05,{ }^{* *}=\mathrm{P}<0.01,{ }^{* * *}=\mathrm{P}<0.001,{ }^{\mathrm{NS}}=$ non-significant. 
Santa Cruz displayed the highest number of alleles (four) registered in Sat 5 and Sol 44 loci. However, in Montecillo Santa Cruz and Santa María del Mar, low allelic frequencies (smaller than $10 \%$ ) were also found: alleles $c$ and $d$ in Sat 5; and allele $b$ in Sat 13, respectively (Table 2).

The Chi-square analysis by locus revealed a significant deviation $(\mathrm{P}<0.001-0.01)$ from HWE in three loci (Sat 3, Sat 5 and Sol 44) of two populations, Santa María del Mar and Montecillo Santa Cruz (Table 2). All loci showed monomorphic states (fixed alleles) in at least one population: Aguachil has one fixed allele in two loci (Sat 5 and Sol 33), San Francisco del Mar Viejo in three loci (Sat 5, Sat 12 and Sol 33), Montecillo Santa Cruz in three loci (Sat 2, Sat 3 and Sol 33), and Santa María del Mar in two loci (Sat 2 and Sol 33) (Table 2). Four exclusive alleles were found in the Montecillo Santa Cruz population (alleles $c$ and $d$ for Sat 5, and alleles $c$ and $d$ for Sol 44), whereas in Aguachil only an exclusive allele was found (allele $c$ for Sat 13). Amplifications were not obtained in the locus Sol 44 for Aguachil and San Francisco del Mar Viejo (Table 2).

Null alleles were detected only in one locus (Sat 5) in individuals from Santa María del Mar. The expected heterozygosity with the INA method was not different from the estimate obtained without considering null alleles $\left(\chi^{2}=0.02\right.$, d.f. $\left.=3, \mathrm{P}=0.99\right)$ (Table 1).

The AMOVA results showed a moderate and significant mean genetic differentiation $\left(F_{\mathrm{ST}}=0.18, \chi^{2}=24.12\right.$, d.f. $\left.=1, \mathrm{P}<0.001\right)$, with the genetic variation mainly distributed within populations $(81.61 \%)$, and low between populations $(18.39 \%)$. The corrected genetic differentiation was $F_{S T}=0.22(\mathrm{P}<0.001)$, considering null alleles $\left(F_{S T-I N A}\right)$ and without null alleles $\left(F_{S T-E N A}\right)$. The calculation of $F_{\mathrm{ST}}$ by pairs of populations showed no genetic differentiation between jackrabbits from Aguachil and San Francisco del Mar Viejo, while the highest genetic differentiation was observed between jackrabbits from Montecillo Santa Cruz and San Francisco del Mar Viejo (0.38) (Table 3).

According to Cavalli-Sforza and Edwards's genetic distances, with the ENA and INA methods (Fig. 2), the greatest distance occurs between the Aguachil and Montecillo Santa Cruz populations $\left(D_{C-E N A}=0.33, D_{C-I N A}=\right.$ 0.35 ), and the smallest distance was between Montecillo Santa Cruz and Santa María del $\operatorname{Mar}\left(D_{C-E N A}=0.18, D_{C-I N A}=0.21\right)$ (Fig. 2). The Bayesian analysis showed that the most

\section{APPENDIX}

Seven microsatellite loci used to determine the genetic diversity and structure of $L$. flavigularis

\begin{tabular}{|c|c|c|c|c|c|}
\hline Locus & $\begin{array}{c}\text { GenBank } \\
\text { accession no. }\end{array}$ & Primer sequence $\left(5^{\prime} 3^{\prime}\right)$ & Size range (bp) & Repetition & $\mathrm{T}_{\mathrm{A}}$ \\
\hline Sat $2^{1}$ & M77195 & $\begin{array}{l}\text { F: GCTCTCCTTTGGCATACTCC } \\
\text { R: GCTTTGGATAGGCCCAGATC }\end{array}$ & $241-253$ & $(\mathrm{TC})_{15}(\mathrm{TG})_{10}$ & $55^{\circ} \mathrm{C}$ \\
\hline Sat $3^{1}$ & J03744 & $\begin{array}{l}\text { F: GGAGAGTGAATCAGTGGGTG } \\
\text { R: GAGGGAAAGAGAGAGACAGG }\end{array}$ & $146-162$ & $(\mathrm{TC})_{22}$ & $60{ }^{\circ} \mathrm{C}$ \\
\hline Sat $5^{1}$ & X99887 & $\begin{array}{l}\text { F: GCTTCTGGCTTCAACCTGAC } \\
\text { R: CTTAGGGTGCAGAATTATAAGAG }\end{array}$ & $206-234$ & $(\mathrm{TC})_{23} \mathrm{TTT}$ & $60^{\circ} \mathrm{C}$ \\
\hline Sat $12^{1}$ & X99891 & $\begin{array}{l}\text { F: CTTGAGTTTTAAATTCGGGC } \\
\text { R: GTTTGGATGCTATCTCAGTCC }\end{array}$ & $122-138$ & $(\mathrm{CTAT})_{10}$ & $55^{\circ} \mathrm{C}$ \\
\hline Sat $13^{1}$ & X99892 & $\begin{array}{l}\text { F: CAGTTTTGAAGGACACCTGC } \\
\text { R: GCCTCTACCTTTGTGGGG }\end{array}$ & $114-128$ & $(\mathrm{GT})_{13}$ & $55^{\circ} \mathrm{C}$ \\
\hline Sol $33^{2}$ & X94683 & $\begin{array}{l}\text { F: GAAGGCTCTGAGATCTAGAT } \\
\text { R: GGGCCAATAGGTACTGATCCATGT }\end{array}$ & $179-221$ & $(\mathrm{TG})_{3} \mathrm{CG}(\mathrm{TG})_{18}$ & $52{ }^{\circ} \mathrm{C}$ \\
\hline Sol $44^{2}$ & X94684 & $\begin{array}{l}\text { F: GGCCCTAGTCTGACTCTGATTG } \\
\text { R: GGTGGGGCGGCGGGTCTGAAAC }\end{array}$ & $140-218$ & $(\mathrm{GT})_{17}$ & $62{ }^{\circ} \mathrm{C}$ \\
\hline
\end{tabular}

\footnotetext{
${ }^{1}=$ Mougel et al. (1997), ${ }^{2}=$ Surridge et al. (1997).
} 


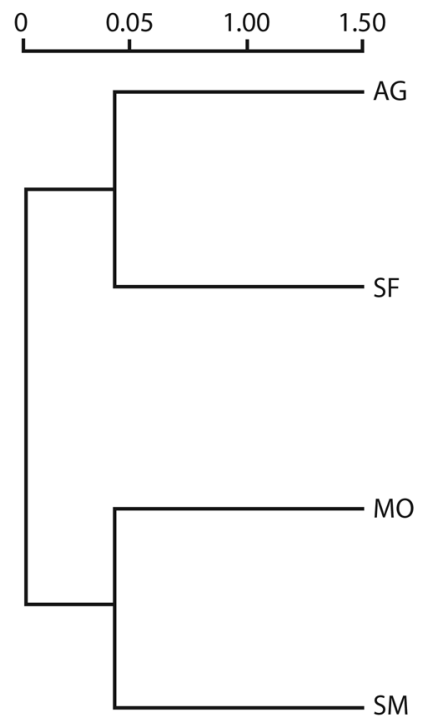

Fig. 2. Genetic distances Cavalli-Sforza \& Edwards (1967) using the INA and ENA methods, among four existing populations of L. flavigularis in Oaxaca, México. AG $=$ Aguachil, $\mathrm{SF}=$ San Francisco del Mar Viejo, $\mathrm{MO}=$ Montecillo Santa Cruz, SM = Santa María del Mar.

probable number of genetic clusters was $K=2$; $39 \%$ of individuals were assigned to Cluster A (jackrabbits of Montecillo Santa Cruz), and 58 $\%$ to Cluster B (jackrabbits of Aguachil, San Francisco del Mar Viejo and Santa María del Mar) (Fig. 3).

The Mantel test yielded non-significant results when geographic distances were compared with genetic distances $(R=0.27, \mathrm{P}=$ $0.42)$, with the genetic differentiation $(R=0.05$,
TABLE 3

Corrected genetic differentiation $\left(F_{S T}\right)$ (Weir 1996) between existing populations of $L$. flavigularis, using the INA method (above the diagonal) and the ENA method (below the diagonal) (Chapuis \& Estoup 2007)

\begin{tabular}{lcccc} 
Populations & AG & SF & MO & SM \\
AG & 0 & $0.02^{\mathrm{NS}}$ & $0.29^{* * *}$ & $0.21^{* * *}$ \\
SF & $0.04^{\mathrm{NS}}$ & 0 & $0.38^{* * *}$ & $0.20^{* * *}$ \\
MO & $0.30^{* * *}$ & $0.38^{* * *}$ & 0 & $0.16^{* * *}$ \\
SM & $0.21^{* * *}$ & $0.22^{* * *}$ & $0.16^{* * *}$ & 0 \\
\hline
\end{tabular}

$\mathrm{AG}=$ Aguachil, $\mathrm{SF}=$ San Francisco del Mar Viejo, $\mathrm{MO}=$ Montecillo Santa Cruz, SM = Santa María del Mar.

${ }^{* *}=\mathrm{P}<0.05,{ }^{* *}=\mathrm{P}<0.01,{ }^{* * *}=\mathrm{P}<0.001$,

NS $=$ non-significant.

$\mathrm{P}=0.20)$ and with linearized genetic differentiation $(R=0.25, \mathrm{P}=0.25)$.

\section{DISCUSSION}

Genetic diversity in L. flavigularis was low $\left(H_{O}=0.30, H_{E}=0.24\right)$, and the values are below those found in other jackrabbit species. For example, in L. americanus was reported an expected heterozygosity of $H_{E}=0.67$ (Burton, Krebs, \& Taylor, 2002), and in L. timidus a $H_{O}$ $=0.422-0.498$ and a $H_{E}=0.537-0.543$ (Andersson, Thulin, \& Tegelström, 1999; Hamill, Doyle, \& Duke, 2006; 2007). In L. europeus a $H_{O}=0.367-0.65$ and a $H_{E}=0.621-0.703$ (Andersson et al., 1999; Fickel et al., 2005; Canu et al., 2013). Whereas, in L. castroviejoi and $L$. granatensis the genetic diversity was

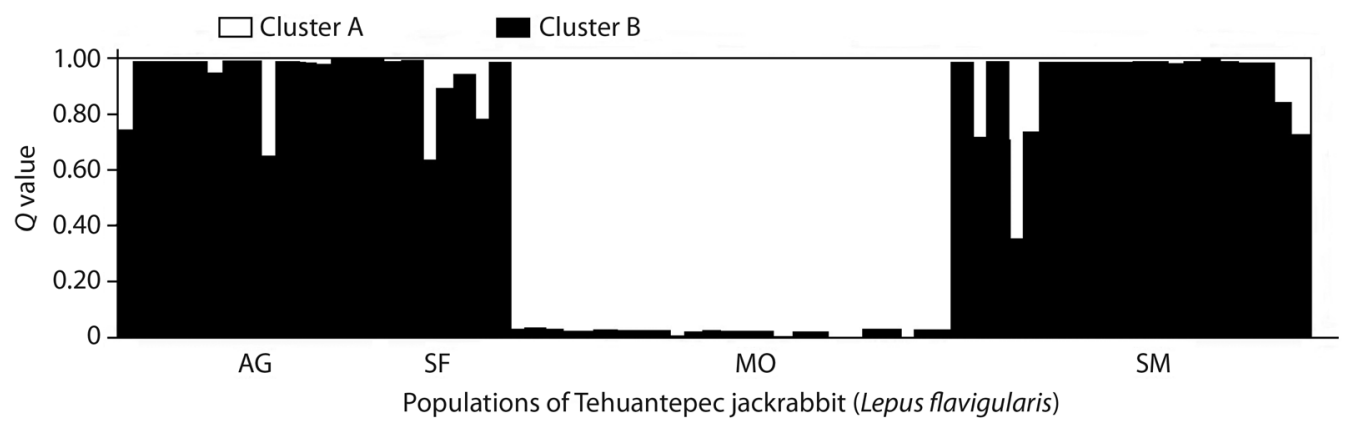

Fig. 3. Bayesian clustering of four existing populations of L. flavigularis in Oaxaca, México. AG = Aguachil, $\mathrm{SF}=\mathrm{San}$ Francisco del Mar Viejo, MO = Montecillo Santa Cruz, SM = Santa María del Mar. 
similar to that in L. flavigularis: $H_{O}=0.325$, $H_{E}=0.256$ in L. castroviejoi; $H_{O}=0.490$, $H_{E}=0.294$ in L. granatensis (Estonba et al., 2005). Microsatellites can vary drastically in their polymorphism, therefore genetic diversity detected can vary according to the set of loci studied (Maudet et al., 2002). Additionally, the geographic distribution and ecological differences between species can substantially affect diversity measures (Berkman, Nielsen, Roy, \& Heist, 2015).

The genetic variation values in L. flavigularis may indicate that has historically maintained small population sizes along with a low genetic diversity. The restricted geographic distribution of L. flavigularis, coupled with evolutionary and ecological processes that occur to a greater extent in small populations (e.g. genetic drift, natural selection), have probably led to low genetic diversity levels (Aguirre-Planter, Furnier, \& Eguiarte, 2000; Frankham, 2005; Eckert, Eckert, \& Hall, 2010; Carrillo-Reyes et al., 2012; Rioja-Paradela et al., 2012; Sántiz et al., 2012). Null alleles were detected at the locus level; however, these showed no influence on the estimated heterozygosity values.

The genetic variation in $L$. flavigularis observed in this study is consistent with previous studies carried out with allozymes (Cervantes et al., 2002), and with mDNA (Rico et al., 2008). Although our results are within the range reported by Cervantes et al. (2002) and Rico et al. (2008), the information obtained with microsatellites is essential to define management units and develop conservation strategies, as these are abundant genome markers and have a high mutation rate that makes them suitable for detecting differences between individuals of the same population and, therefore, for identifying recent genetic variation and differentiation, which is not possible with sequences of mDNA and allozymes (Rentaría, 2007; Demarchi, 2009).

Among the populations studied, Montecillo Santa Cruz showed the greater genetic diversity, followed by Santa María del Mar. In contrast, San Francisco del Mar Viejo (population with the smallest population size) showed the lowest genetic variation, with the lowest number of alleles, heterozygosity and polymorphic loci, all of which makes its the population, at higher risk of extinction. The presence of fixed alleles at all loci studied and in all populations, as well as the low genetic diversity, especially in San Francisco del Mar Viejo, suggests the effect of genetic drift, which promotes the fixing of alleles and loss of genetic diversity in small populations (Frankham et al., 2002). Nevertheless, it is necessary to evaluate these conclusions in future studies, using a greater number of microsatellites and molecular markers specifically designed for L. flavigularis, with the purpose of diminishing the effect the non-specificity of the molecular markers used to evaluate polymorphism levels in this study.

The lack of amplification of the locus Sol 44 in San Francisco del Mar Viejo and Aguachil, could be due to mutations in the flanking region of a microsatellite that cause the lack of alignment in the genome sequence (Hedrick, 2005; Pompanon, Bonin, Bellemain, \& Taberlet, 2005). However, the possibility of bias is not ruled out, as the markers used were designed for other species (Mougel et al., 1997; Surridge et al., 1997).

The mean genetic differentiation $\left(F_{\mathrm{ST}}\right)$ was moderate and statistically significant $\left(F_{\mathrm{ST}}=\right.$ $0.18, \mathrm{P}<0.001)$, both in terms of corrected and uncorrected frequencies. The genetic differentiation between pairs of populations ranged from zero to moderate, using null alleles (INA) and not using null alleles (ENA). Aguachil and San Francisco del Mar Viejo showed no genetic differentiation; consequently, these could be considered as a management unit (Moritz, 1994; Pullin, 2002). Genetic drift is likely to affect each one of the studied populations of $L$. flavigularis, causing the genetic differentiation in the absence of gene flow, and its effect could be stronger in small populations (Frankham et al., 2002; Hedrick, 2005; Keyghobadi, 2007). Genetic structure may be associated with morphological differences between populations, which may be caused by natural selection (Frankham et al., 2002; Vinu et al., 2013). Biometric differences between populations 
of L. flavigularis have been partially studied; Rico, Lorenzo, and López, (2012), reported a differentiation in body size between jackrabbits from Santa María del Mar vs. Montecillo Santa Cruz and Aguachil, which is associated with a possible effect of the local environmental characteristics (e.g. availability and quality of food). It is important to evaluate the relations of morphological variations with genetic structure, including four existing populations, because in this way it can identify local evolutionary processes, and avoid the effects of outbred depression by translocation of individuals between populations (Frankham, 2005; Rico et al., 2012).

The estimation of molecular variance (AMOVA) was greater within than between populations, a finding that may indicate mating among genetically distant individuals within populations, and reproductive isolation with limited gene flow between populations (Hedrick, 2005; Keyghobadi, 2007). Habitat loss and fragmentation, along with a polygamous behavior and lack of territoriality in L. flavigularis (Rioja, Lorenzo, Naranjo, Scott, \& Carrillo-Reyes, 2008; Carrillo-Reyes et al., 2010), explain the higher proportion of genetic diversity within populations.

The inclusion of null alleles did not modify genetic distances. The dendrograms (INA and ENA methods) revealed two clades that clustered Montecillo Santa Cruz with Santa María del Mar, and Aguachil with San Francisco del Mar Viejo, indicating a greater similarity between these pairs of populations. According to Euclidean distances, the closest populations were San Francisco del Mar and Montecillo Santa Cruz $(18.02 \mathrm{~km})$, and the most distant were Aguachil and Santa Maria del Mar (38.34 $\mathrm{km})$. Geographic distances are not associated with genetic distances in populations of L. flavigularis; the Mantel tests did not detect isolation by distance, suggesting that genetic distances and genetic differentiation are not determined by geographic distances among populations. However, geographical barriers such as geographical faults, roads, highways or floods due to changes in sea level, can lead to population isolation and explain the genetic distances observed (Rico et al., 2008).

The Bayesian analysis showed that genetic structure grouped the populations studied into two clusters: jackrabbits of Montecillo Santa Cruz in Cluster A, and jackrabbits of San Francisco del Mar Viejo, Aguachil y Santa María del Mar in Cluster B. Our results do not agree with those reported by Rico et al. (2008), who identified two clades based on mDNA, one grouping the populations Montecillo Santa Cruz, San Francisco del Mar Viejo and Aguachil, and the other including jackrabbits of Santa María del Mar. Different patterns of genetic structure based on different markers may be due to a number of factors, including mutation rates, timescale and life history of the species (Arteaga, Piñero, Eguiarte, Gasca, \& Medellín, 2012). Mitochondrial DNA is maternally inherited, more conservative and detects historical information; microsatellites are segregated according to Mendelian laws, have high mutation rates and indicate recent genetic variation patterns (Goldstein \& Pollock, 1994; Vendramin, Lelli, Rossi, \& Morgante, 1996; Demarchi, 2009). The results found in this study suggest a relative gene flow between the populations located South of Laguna Inferior in the Gulf of Tehuantepec coast (i.e. San Francisco del Mar Viejo, Santa María del Mar and Aguachil), differences in the dispersion (gene flow) of males and females (Carrillo-Reyes et al., 2010), and modifications in the connectivity of populations through time, possibly associated with variations in climate and human activities (e.g. temperature, precipitation, changes in sea level, land cover and land uses, human settlements, agricultural areas; Sántiz et al., 2016) that serve as barriers or corridors, and determine the displacement of organisms throughout the landscape.

Nevertheless, the estimated $F_{S T}$ values by pairs of populations suggest a moderate gene flow only between Aguachil and San Francisco del Mar Viejo, while indicated genetic isolation for the other populations, these values are consistent with geographical barriers present in the area (e.g. the sea channel between 
San Francisco del Mar Viejo and Santa María del Mar) (Rico et al., 2008). The low gene flow detected among most populations suggests high inbreeding levels (heterozygote deficit); by contrast, our results revealed an excess of heterozygotes, which could be explained by breeding groups or sub-populations that cause sub-structure (Surridge, Bell, \& Hewitt, 1999). As spatial scale increases from a breeding group to the population level, the rate of inbreeding relative to that expected, in a random mating scenario, is modified, hence, at the smallest level within which individuals interbreed, and an increased observed heterozygosity relative to the one expected (excess heterozygosity) may be found (Surridge et al., 1999; Frankham et al., 2002).

Management and conservation programs for L. flavigularis should consider a detailed short- and long-term research based on the alleles found in the present study. It is particularly important to monitor the exclusive alleles detected in the Montecillo Santa Cruz and Aguachil populations, as well as the variations in allelic frequencies, in order to detect the loss or gain of alleles, and identify the processes that could be involved in such changes. Furthermore, it is essential to monitor the displacement of individuals among populations that show no evidence of gene flow, since unfortunately it is not possible to establish permanent wildlife corridors to promote the regular movements of individuals across the distribution range driven by climatic events (e.g. floods and droughts), human settlements, agriculture and cattle ranches (Rioja-Paradela et al., 2012; Sántiz et al., 2016).

Based on the genetic structure and distances between populations observed in this study, we suggest two management units that can be very useful to reestablish gene flow between populations and to develop effective conservation strategies: (1) Montecillo Santa Cruz and Santa María del Mar, and (2) Aguachil and San Francisco del Mar Viejo. To define a translocation strategy, it is urgent to carry out more studies of population genetics with specific and highly polymorphic molecular markers that help define the steps to follow for the movement of individuals among existing populations. Also, a research focused on genetic consequences of inbreeding and outbreeding has to be carryied out. Likewise, it is imperative to control fires, changes in land use and poaching (and overhunting) to protect the existing populations of $L$. flavigularis and their habitats (Carrillo-Reyes et al., 2010; 2012; Rioja-Paradela et al., 2012). Further research should also be conducted considering captive breeding programs and reintroduction to potential areas, based on the genetic diversity, distances and structure detected (Rioja-Paradela et al., 2012; Verde et al., 2015).

\section{ACKNOWLEDGMENTS}

We are grateful to all those who assisted in field work, specially to the family Gutiérrez Vázquez, Antonio Gutiérrez, Jorge Bolaños and Felipe Barragán. We also thank to Aldo Gómez and Maricela García for their invaluable support and participation in the laboratory work, and Darío Navarrete Gutiérrez for his help in the construction the map. The Consejo Nacional de Ciencia y Tecnología (CONACyT) through the Fondos Mixtos de Apoyo a la Investigación Científica CONACyT-Gobierno del Estado de Chiapas (CHIS-2005-C03-001), for their financial support to carry out this research. María Elena Sánchez Salazar collaborated in the edition of this manuscript.

\section{RESUMEN}

Variación y estructura genética de la liebre en peligro de extinción, Lepus flavigularis (Lagomorpha: Leporidae). Lepus flavigularis es una especie endémica y en peligro, con solo cuatro poblaciones ubicadas en Oaxaca, México: Montecillo Santa Cruz, Aguachil, San Francisco del Mar Viejo y Santa María del Mar. Las actividades humanas (e.g. cacería, cambios de uso de suelo) y la baja diversidad genética detectada con ADN mitocondrial y aloenzimas muestran la urgencia de desarrollar estrategias de manejo para esta especie. Para definir unidades de manejo es necesario estudiar la estructura genética con genes nucleares debido a su herencia y alto polimorfismo, por lo tanto, el objetivo de este estudio fue examinar la variación y estructura genética de L. flavigularis 
con microsatélites nucleares. Se obtuvo el ADN genómico de 67 liebres de las cuatro poblaciones de L. flavigularis, capturadas mediante muestreo nocturno de 2001 a 2006, mediante el método fenol-cloroformo-alcohol isoamílico. Para obtener la diversidad y estructura genética se amplificaron siete microsatélites con la Reacción en Cadena de la Polimerasa (PCR). Las amplificaciones se visualizaron mediante electroforesis con geles de poliacrilamida al 10 $\%$, teñidas con bromuro de etidio. La diversidad genética se determinó con el programa GenAlEx v.6.4, y la estructura genética se obtuvo con el ARLEQUIN v.3.1. Se evaluaron los alelos nulos con el programa Micro-Checker v.2.2.2. Adicionalmente, se realizó un análisis bayesiano con el software STRUCTURE v.2.2.3, y se estudió el aislamiento por distancia (IBD) mediante el programa PASSAGE v.2.0.11.6. La variación genética encontrada fue baja $\left(H_{O}\right.$ $\left.=0.30, H_{E}=0.24\right)$ en comparación con otras especies de liebres. Se detectaron alelos fijos y diferenciación genética moderada $\left(F_{\mathrm{ST}}=0.18, \mathrm{P}<0.001\right)$ entre las poblaciones, lo que indica el efecto de la deriva genética y flujo genético limitado. El análisis Bayesiano reveló dos grupos: (1) liebres de Montecillo Santa Cruz, e (2) individuos de Aguachil, San Francisco del Mar Viejo y Santa María del Mar. No se detectó evidencia de aislamiento por distancia. Es posible que las barreras geográficas presentes entre las poblaciones (e.g. lagunas, asentamientos humanos), más que la distancia geográfica entre ellas, expliquen la estructura genética observada. El coeficiente de endogamia fue negativo $\left(F_{I S}=-0.27, \mathrm{P}=0.03\right)$, indicando sub-estructura genética en las poblaciones. Sugerimos dos unidades de manejo con base en las poblaciones más cercanas genéticamente, lo que ayudará a definir acciones precisas de conservación en L. flavigularis. Esta investigación es la base para definir la translocación de individuos entre las poblaciones, sin embargo, se requiere un estudio futuro más amplio que incorpore marcadores moleculares específicos para L. flavigularis. Asimismo, es necesario analizar las barreras que limitan el flujo genético, ya que es urgente reducir la diferenciación genética entre poblaciones e incrementar la diversidad genética de esta especie.

Palabras clave: especies endémicas, genética de la conservación, Lepus flavigularis, liebre tropical, microsatélites, unidades de manejo.

\section{REFERENCES}

Aguirre-Planter, E., Furnier, G. R., \& Eguiarte, L. E. (2000). Low levels of genetic variation within and high levels of genetic differentiation among populations of species of Abies from southern México and Guatemala. American Journal of Botany, 87(3), 362371 (doi: 10.2307/2656632).

Andersson, A. C., Thulin, C. G., \& Tegelström, H. (1999). Applicability of Rabbit microsatellite primers for Studies of hybridization between an introduced and a native hare species. Hereditas, 130(3), 309-315 (doi: 10.1111/j.1601-5223.1999.00309.x).

Arteaga, M. C., Piñero, D., Eguiarte, L. E., Gasca, J., \& Medellín, R. A. (2012). Genetic structure and diversity of the nine-banded armadillo in México. Journal of Mammalogy, 93(2), 547-559 (doi: 1644/11-MAMM-A-211.1).

Berkman, L. K., Nielsen, C. K., Roy, C. L., \& Heist, E. J. (2015). Comparative genetic structure of sympatric leporids in southern Illinois. Journal of Mammalogy, 96(3), 552-563 (doi:10.1093/jmammal/gyv060).

Burton, C., Krebs, C. J., \& Taylor, E. B. (2002). Population genetic structure of the cyclic snowshoe hare (Lepus americanus) in southwestern Yukon, Canada. Molecular Ecology, 11(9), 1689-1701 (doi: 10.1046/j.1365-294X.2002.01566.x).

Canu, A., Scandura, M., Luchetti, S., Cossu, A., Iacolina, L., Bazzanti, M., \& Apollonio, M. (2013). Influence of management regime and population history on genetic diversity and population structure of Brown hares (Lepus europaeus) in an Italian province. European Journal of Wildlife Research, 59(6), 783-793 (doi: 0.1007/s10344-013-0731-x).

Carrillo-Reyes, A., Lorenzo, C., Naranjo, E., Pando, M., \& Rioja, T. (2010). Home range dynamics of the Tehuantepec jackrabbit in Oaxaca, México. Revista Mexicana de Biodiversidad, 81(1), 143-1514 (Recovered from http://uaech.redalyc.org/articulo. oa?id=4215998019).

Carrillo-Reyes, A., Lorenzo, C., Rioja-Paradela, T., Naranjo, E., \& Pando, M. (2012). Uso de hábitat de la liebre en peligro de extinción, Lepus flavigularis: implicaciones para su conservación. Therya, 3(2), 113-125 (doi: 10.12933/therya-12-63).

Cavalli-Sforza, L. L., \& Edwards, A. W. F. (1967). Phylogenetic analysis: models and estimation procedures. The American Journal of Human Genetics, 19(3), 233-257.

Cervantes, F. A., Lorenzo, C., Farías, V., \& Vargas, J. (2008). Lepus flavigularis IUCN Red List of Threatened Species. Version 2014.3 (Recovered from www. iucnredlist.org).

Cervantes, F. A., Lorenzo, C., \&Yates, T. L. (2002). Genic Variation in Populations of Mexican Lagomorphs. Journal of Mammalogy, 83(4), 1077-1086 (Recovered from http://dx.doi. org/10.1644/1545-542(2002)083<1077:GVIPOM >2 .0.CO;2).

Chapuis, M-P., \& Estoup, A. (2007). Microsatellite null alleles and estimation of population differentiation. Molecular Biology and Evolution, 24(3), 621-631 (doi: 10.1093/molbev/ms1191). 
Cruz-Salazar, B., Ruiz-Montoya, L., Vázquez-Domínguez, E., Navarrete-Gutiérrez, D., Espinoza-Medinilla, E. E., \& Vázquez, L. B. (2016). Journal Tropical Ecology, 32(2), 146-157 (doi: 10.1017/ SO266467416000080).

Demarchi, D. A. (2009). Microsatélites, distancias genéticas y estructura de poblaciones nativas sudamericanas. Revista Argentina de Antropología Biológica, 11(1), 73-88 (Recovered from http://www.revistas. unlp.edu.ar/raab/article/viewFile/269/126).

Eckert, A. J., Eckert, M. L., \& Hall, B. D. (2010). Effects of historical demography and ecological context on spatial patterns of genetic diversity within foxtail pine (Pinus balfouriana; Pinaceae) stands located in the Klamath Mountains, California. American Journal of Botany, 97(4), 650-659 (doi: 10.3732/ajb.0900099).

Encinas, D. J. F., da Silva, B. M., da Silva, I. V., da Silva, C. J., \& Sebbenn, A. M. (2016). Diversity and spatial genetic structure of a natural population of Theobroma speciosum (Malvaceae) in the Brazilian Amazon. Revista de Biología Tropical, 64(3), 1091-1099 (doi: 10.15517/rbt.v64i3.21461).

ESRI (Environmental Systems Research Institute). (2011). ArcGIS Desktop: release 10, Environmental Systems Research Institute. Redlands, USA.

Estonba, A., Solís, A., Iriondo, M., Sanz-Martín, M. J., Pérez-Suárez, G., Markov, G., \& Palacios, F. (2005). The genetic distinctiveness of the three Iberian hare species: Lepus europaeus, L. granatensis, and $L$. castroviejoi. Mammalian Biology, 71(1), 52-29 (doi: 10.1016/j.mambio.2005.08.010).

Evanno, G., Regnaut, S., \& Goudet, J. (2005). Detecting the number of clusters of individuals using the software STRUCTURE: a simulation study. Molecular Ecology, 14(8), 2611-2620 (doi: 10.1111/j.1365-294X.2005.02553.x).

Excoffier, L., \& Lischer, H. E. L. (2010). Arlequin suite ver 3.5: a new series of programs to perform population genetics analyses under Linux and Windows. Molecular Ecology Resources, 10(3), 564-567 (doi: 10.1111/j.1755-0998.2010.02847.x).

Excoffier, L., Smouse, P. E., \& Quattro, J. M. (1992). Analysis of molecular variance inferred from metric distances among DNA haplotypes: application to human mitochondrial DNA restriction data. Genetics, 131(2), 479-491 (Recovered from http://www.genetics.org/content/131/2/479.full.pdf).

Falush, D., Stephens, M., \& Pritchard, J. K. (2003). Inference of population structure: extensions to linked loci and correlated allele frequencies. Genetics, 164(4), 1567-1687 (Recovered from http://www.genetics. org/cgi/pmidlookup?view=long\&pmid=12930761).

Farías, V., Fuller, T. K., Cervantes, F. A., \& Lorenzo, C. (2006). Home range and social behavior of the endangered Tehuantepec jackrabbit (Lepus flavigularis) in Oaxaca, México. Journal of Mammalogy, 87(4), 748-756 (Recovered from http:/www.jstor. org/stable/4094602).

Fickel, J., Schmidt, A., Putze, M., Spittler, H., Ludwig, A., Juergen, S. W., \& Pitra, C. (2005). Genetic structure of populations of European brown hare: implications for management. The Journal of Wildlife Management, 69(2), 760-770 (Recovered from http://www. jstor.org/stable/3803747).

Frankham, R. J. (2005). Stress and adaptation in conservation genetics. Journal of Evolutionary Biology, 18(4), 750-755 (doi: 10.1111/j.1420-9101.2005.00885.x).

Frankham, T. J., Ballou, J. D., \& Briscoe, D. A. (2002). Introduction to conservation genetics. New York, USA: Cambridge University Press.

Freeland, J.(2005). The evolution of population biology: past, present and future. Journal of Biogeography, 32(11), 2039-2040 (doi: 10.1111/j.1365-2699.2005.01363.x).

Gannon, W. L., Sikers, R. S., \& The animal care and use committee of the American Society of Mammalogists. (2007). Guidelines of the American Society of Mammalogists for the use of wild mammals in research. Journal of Mammalogy, 88(3), 804-823 (Recovered from http://www.mammalsociety.org/ articles/guidelines-american-society-mammalogistsuse-wild-mammals-research-0).

García, E. (1988). Modificaciones al sistema de clasificación climática de Köpen (para adaptarlo a las condiciones de la República Mexicana). Ciudad de México, México: Instituto de Geografía, Universidad Nacional Autónoma de México.

Goldstein, D. B., \& Pollock, D. D. (1994). Least squares estimation of molecular distance - noise abatement in phylogenetic reconstruction [online]. Theoretical Population Biology, 45(3), 219-226 (doi: 10.1006/ tpbi.1994.1012).

Hamill, R. M., Doyle, D., \& Duke, E. J. (2006). Spatial patterns of genetic diversity across European subspecies of the mountain hare, Lepus timidus L. Heredity, 97(5), 355-365 (doi: 10.1038/sj.hdy.6800880).

Hamill, R. M., Doyle, D., \& Duke, E. J. (2007). Microsatellite analysis of mountain hares (Lepus timidus hibernicus): low genetic differentiation and possible sex-bias in dispersal. Journal of Mammalogy, 88(3), 784-792 (Recovered from http://www.jstor. org/stable/4498719).

Hamilton, M., Pincus, E., Di Fiore, A. \& Fleischer, R. C. (1999). Universal linker and ligation procedures for construction of genomic DNA libraries enriched for microsatellites. BioTechniques, 27(3), 500-507 (doi: 91199917). 
Hedrick, P. W. (2005). Genetics of populations. Massachusetts, USA: Jones and Bartlett Publishers.

Hennessy, C., Tsai, C. C., Beasley, J. C., Beatty, W. S., Zollner, P. A., \& Rhodes, O. E. (2015). Elucidation of population connectivity in synanthropic mesopredators: using genes to define relevant spatial scales for management of raccoons and Virginia opossums. The Journal Wildlife Management, 79(1), 112-121 (doi: 10.1002/jwmg.812).

International Union for Conservation of Nature (IUCN). (2015). The IUCN red list of Threatened species, Version 2016-1 (Recovered from www.iucnredlist.org).

Keyghobadi, N. (2007). The genetic implications of habitat fragmentation for animals. Canadian Journal of Zoology, 85(10), 1049-1064 (doi: 10.1139/Z07-095).

Lorenzo, C., Carrillo-Reyes, A., Rioja-Paradela, T. M., De La Paz, M. C., Bolaños-Citalán, J., \& ÁlvarezCastañeda, S. T. (2014). Estado actual de conservación de liebres y conejos en categoría de riesgo en México (Final Report, Proyect HK052). Mexico City, México: CONABIO.

Lorenzo, C., Cervantes, F. A., Barragán, F., \& Vargas, J (2006). New records of the endangered Tehuantepec jackrabbit (Lepus flavigularis) from Oaxaca, México. The Southwestern Naturalist, 51(1), 116-119 (doi: 10.1894/0038-4909(2006)51[116:NROTET]2. $0 . \mathrm{CO} ; 2)$.

Lorenzo, C., Cervantes, F. A., \& Vargas, J. (2005). Conservación de la liebre Lepus flavigularis, especie en peligro de extinción. Chiapas (Informe Final). CONACYT-SEMARNAT, México.

Lorenzo, C., Rioja-Paradela, T. M., \& Carrillo-Reyes, A. (2015). State of knowledge and conservation of endangered and critically endangered lagomorphs worldwide. Therya, 6(1), 11-30 (doi: 10.12933/ therya-15-225).

Lorenzo, C., Rioja, T. M., Carrillo, A., \& Cervantes, F. A. (2008). Population fluctuations of Lepus flavigularis (Lagomorpha: Leporidae) at Tehuantepec Isthmus, Oaxaca, México. Acta Zoológica Mexicana, 24(1), 207-220 (Recovered from http://www.redalyc.org/ articulo.oa? id=57524111).

Mace, G. M., Smith, T. B., Bruford, M. W., \& Wayne, R. K. (1996). An overview of the issues. In T. B. Smith, \& R. K. Wayne (Eds.), Molecular genetic approaches in conservation (pp. 3-21). New York, USA: Oxford University Press, Inc.

Maudet, C., Miller, C., Bassano, B., Breitenmoser-Würsten, C., Gauthier, D., Obexer-Ruff, G., Michallet, J., Taberlet, P., \& Luikart, G. (2002). Microsatellite DNA and recent statistical methods in wildlife conservation management: applications in Alpine ibex [Capra ibex (ibex)]. Molecular Ecology, 11(3), 421436 (doi: 10.1046/j.0962-1083.2001.01451.x).
Mech, S. G., \& Hallet, J. G. (2001). Evaluating the effectiveness of corridors: a genetic approach. Conservation Biology, 15(2), 467-474 (doi: 10.1046/j.1523-1739.2001.015002467.x).

Moritz, C. (1994). Defining 'evolutionarily significant units' for conservation. Trends in Ecology \& Evolution, 9(10), 373-374 (doi: 10.1016/0169-5347(94)90057-4).

Mougel, F., Mounolou, J. C., \& Monnerot, M. (1997). Nine polymorphic microsatellite loci in the rabbit, Oryctolagus cuniculus. Animal Genetics, 28(1), 58-71 (Recovered from http://www.genomics.liv.ac.uk/ tryps/papers/40ZANKEMP.pdf).

Nei, M. (1972). Genetic distances between populations. The American Naturalist, 106 (949), 283-292 (Recovered from http://www.jstor.org/stable/2459777).

Nei, M. (1978). Estimation of average heterozygosity and genetic distance from a small number of individuals. Genetics, 89(3), 583-590 (Recovered from http:// www.genetics.org/content/89/3/583).

Ortiz, P., Hernández, J. R., \& Figueroa, J. M. (2004). Reconocimiento fisiográfico y geomorfológico. In A. J. García-Mendoza, M. J. Ordóñez, \& M. BrionesSalas (Eds.), Biodiversidad de Oaxaca (pp. 43-54). Ciudad de México, México: Instituto de Biología, UNAM-Fondo oaxaqueño para la conservación de la naturaleza-World Wildlife Fund.

Peakall, R., \& Smouse, P. E. (2006). GENALEX 6: genetic analysis in Excel. Population genetic software for teaching and research. Molecular Ecology Notes, 6(1), 288-295 (doi: 10.1111/j.1471-8286.2005.01155.x).

Pompanon, F., Bonin, A., Bellemain, E., \& Taberlet, P. (2005). Genotyping errors: causes, consequences and solutions. Nature Review Genetics, 6(11), 847-859 (doi: 10.1038/nrg1707).

Pritchard, J. K., Stephens, M., \& Donnelly, P. (2000). Inference of population structure using multilocus genotype data. Genetics, 155(2), 945-959 (doi: 10.1111/j.1417-8286.2007.01758.x).

Pullin, A. S. (2002). Conservation biology. New York, USA: Cambridge University Press.

Rentaría, A. M. (2007). Breve revisión de los marcadores moleculares. In L. E. Eguiarte, V. Souza, \& X. Aguirre (Eds.), Ecología molecular (pp. 541-566). Ciudad de México, México: Instituto Nacional de Ecología, Semarnat.

Rico, Y., Lorenzo, C., González-Cózatl, F. X., \& Espinoza, E. (2008). Phylogeography and population structure of the endangered Tehuantepec jackrabbit Lepus flavigularis: implications for conservation. Conservation Genetics, 9(6), 1467-1477 (doi: 10.1007/ s10592-007-9480-2). 
Rico, Y., Lorenzo, C., \& López, S. (2012). Diferenciación poblacional en la talla corporal de la liebre de Tehuantepec (Lepus flavigularis). Acta Zoológica Mexicana, 24(3), 179-189 (Recovered from http:// www.redalyc.org/articulo.oa?id=57524311).

Rioja-Paradela, T., Carrillo-Reyes, A., \& Lorenzo, C. (2012). Análisis de población viable para determinar el riesgo de extinción de la liebre de Tehuantepec (Lepus flavigularis) en Santa María del Mar, Oaxaca. Therya, 3(2), 137-150 (doi: 10.12933/therya-12-67).

Rioja, T., Lorenzo, C., Naranjo, E., Scott, L., \& CarrilloReyes, A. (2008). Polygynous mating behavior in the endangered Tehuantepec jackrabbit (Lepus flavigularis). Western North American Naturalist, 68(3), 343349 (doi: 10.3398/1527-0904(2008)68[343:PMBITE ]2.0.CO;2.).

Ripperger, S. P., Tschapka, M., Kalko, E. K. V., RodríguezHerrera, B., \& Mayer, F. (2014). Resisting habitat fragmentation: high genetic connectivity among populations of the frugivorous bat Carollia castanea in an agricultural landscape. Agriculture Ecosystems \& Environment, 18(5), 9-15 (doi: 10.1016/j. agee.2013.12.006.).

Rosenberg, M. S., \& Anderson, C. D. (2011). PASSaGE: pattern analysis, spatial statistics and geographic exegesis, version 2.0.11.6. Methods in Ecology and Evolution, 2(3), 229-232 (doi: 10.1111/j.2041-210X.2010.00081.x).

Sántiz, E. C., González-Romero, A., Lorenzo, C., GallinaTessaro, S., \& Cervantes, F. A. (2012). Uso y selección de asociaciones vegetales por la liebre de Tehuantepec (Lepus flavigularis) en Oaxaca, México. Therya, 3(2), 127-136 (doi: 10.12933/therya-12-70).

Sántiz, E. C., Lorenzo, C., Carrillo-Reyes, A., Navarrete, D. A., \& Islebe, G. (2016). Effect of climate change on the distribution of a critically threatened species. Therya, 7(1), 147-159 (doi: 10.12933/therya-16-358).

Schooley, R. L., \& Branch, L. C. (2011). Habitat quality of source patches and connectivity in fragmented landscapes. Biodiversity and Conservation, 20(8), 1611-1623 (doi: 10.1007/s10531-011-0049-5).

Smith, A. T. (2008). Conservation of endangered lagomorphs. In P. C. Alves, N. Ferrand, \& K. Hackländer (Eds.), Lagomorph biology: evolution, ecology, and conservation (pp. 297-315). Berlin, Germany: Springer.

Sokal, R. R., \& Rohlf, F. J. (2003). Biometry. The principles and practice of statistics in biological research. New York, USA: H. Freeman and Company.

Surridge, A. K., Bell, D. J., \& Hewitt, M. (1999). From population structure to individual behavior: genetic analysis of social structure in the European wild rabbit (Oryctolagus cuniculus). Biological Journal of the Linnean Society, 68(1-2), 57-71 (Recovered from http://www.idealibrary.com).
Surridge, A. K., Bell, D. J., Rico, C., \& Hewitt, G. M. (1997). Polymorphic microsatellite loci in the European rabbit (Oryctolagus cuniculus) are also amplified in other lagomorph species. Animal Genetics, 28(4), 302-305 (doi: 10.1111/j.1365-2052.1997.00137.x).

Templeton, A. R. (1986). Coadaptation and outbreeding depression. In M. E. Soule (Ed.), Conservation biology the science of scarcity and diversity (pp. 584-595). Sunderland, Germany: Sinauer Associates, Inc., Publishers.

Templeton, A. R., Shaw, K., Routman, E., \& Scott, D. K. (1990). The genetic consequences of habitat fragmentation. Annals of the Missouri Botanical Garden, 77(1), 13-27 (doi: 10.2307/2399621).

Van Oosterhout, C., Hutchinson, W. F., Willis, D. P. M., \& Shipley, P. (2004). Micro-checker: for identifying and correcting genotyping error in microsatellite data. Molecular Ecology Notes, 4(3), 535-538 (doi: 10.1111/j.1471-8286.2004.00684.x).

Valadez, M. H., \& Kahl, G. (2000). Huellas de ADN en el genoma de plantas. Ciudad de México, México: Mundi Prensa.

Vendramin, G. G., Lelli, L., Rossi, P., \& Morgante, M. (1996). A set of primers for the amplification of 20 chloroplast microsatellites in Pinaceae. Molecular Ecology, 5(4), 595-598 (doi: 10.1111/j.1365294X.1996.tb00353.x).

Verde, A. L. D., Leach, K., Reid, N., \& Fisher, D. O. (2015). Diversity, extinction, and threat status in lagomorphs. Ecography, 38(11), 1155-1165 (doi: 10.1111/ecog.01063).

Vinu, V., Singh, N., Vasudev, S., Kumar Yadava, D., Kumar, S., Naresh, S., Ramachandra Bhat, S., \& Vinod Prabhu, K. (2013). Assessment of genetic diversity in Brassica juncea (Brassicaceae) genotypes using phenotypic differences and SSR markers. Revista de Biología Tropical, 61(4), 1919-1934 (doi: http://dx.doi.org/10.15517/rbt.v61i4).

Weir, B. S. (1996). Genetic Data Analysis II. Sunderland, England: Sinauer Associates.

Weir, B. S., \& Cockerhamm, C. C. (1984). Estimating F-statistics for the analysis of population structure. Evolution, 38(6), 1358-1370 (doi: 10.2307/2408641).

Wilson, A., Nishi, J. S., Elkin, B. T., \& Strobeck, C. (2005). Effects of a recent founding event and instrinsic population dynamics on genetic diversity in an ungulate population. Conservation Genetics, 6(6), 905-916 (doi: 10.1007/s10592-005-9077-6).

Zizumbo, D., \& Colunga, P. (1982). Los huaves. La apropiación de los recursos naturales. Estado de México, México: Universidad Autónoma de Chapingo, Texcoco. 